\title{
Tyrosine Phosphorylation of Nicotinic Acetylcholine Receptor Mediates Grb2 Binding
}

\author{
Marcie Colledge and Stanley C. Froehner \\ Department of Physiology, University of North Carolina at Chapel Hill, Chapel Hill, North Carolina 27599
}

Tyrosine phosphorylation of the nicotinic acetylcholine receptor $(\mathrm{AChR})$ is associated with an altered rate of receptor desensitization and also may play a role in agrin-induced receptor clustering. We have demonstrated a previously unsuspected interaction between Torpedo AChR and the adaptor protein Grb2. The binding is mediated by the Src homology 2 (SH2) domain of Grb2 and the tyrosine-phosphorylated $\delta$ subunit of the AChR. Dephosphorylation of the $\delta$ subunit abolishes Grb2 binding. A cytoplasmic domain of the $\delta$ subunit contains a binding motif ( $p Y X N X$ ) for the $\mathrm{SH} 2$ domain of Grb2. Indeed, a phosphopeptide corresponding to this region of the $\delta$ subunit binds to Grb2 SH2 fusion proteins with relatively high affinity, whereas a peptide lacking phosphorylation on tyrosine exhibits no binding. Grb2 is colocalized with the AChR on the innervated face of Torpedo electrocytes. Furthermore, Grb2 specifically copurifies with AChR solubilized from postsynaptic membranes. These data suggest a novel role for tyrosine phosphorylation of the AChR in the initiation of a Grb2mediated signaling cascade at the postsynaptic membrane.

Key words: acetylcholine receptor; tyrosine phosphorylation; Grb2; SH2 domain; postsynaptic specialization; signal transduction
Tyrosine phosphorylation is a critical event in the transduction of signals in many cell types. This reversible post-translational modification often functions to trigger the assembly of transient protein-protein complexes. The identification of protein-binding modules that specifically recognize phosphotyrosine has led to the characterization of downstream effectors of tyrosine kinases. The Src homology 2 (SH2) domain (Koch et al., 1991) and the more recently identified protein tyrosine binding (PTB) domain (Blaikie et al., 1994; Kavanaugh and Williams, 1994) each recognize phosphotyrosine in the context of a specific sequence of amino acids (Songyang et al., 1993, 1995b; Kavanaugh et al., 1995). These domains are found in diverse intracellular signaling molecules, including protein kinases and phosphatases, as well as modular adaptor proteins. The latter proteins, which include Shc, p85, and Grb2, lack any apparent enzymatic activity but are composed almost entirely of multiple protein-binding domains (Pawson, 1995). Thus, recruitment of adaptor proteins to tyrosinephosphorylated proteins provides a scaffold on which signal transduction components can be assembled (for review, see Cohen et al., 1995; Pawson, 1995).

Ligand-driven dimerization of growth factor receptors leads to autophosphorylation of the receptor on tyrosine residues, creating a high-affinity docking site for $\mathrm{SH} 2$ domain-containing proteins

Received Feb. 10, 1997; revised April 8, 1997; accepted April 14, 1997.

This work was supported by a grant (to S.C.F.) from the National Institutes of Health and a fellowship (to M.C.) from the Natural Sciences and Engineering Research Council of Canada. We thank Drs. Neal Kramarcy and Robert Sealock (University of North Carolina) for assistance with confocal microscopy and Dr. Chris Lombardo (Macromolecular Interactions Facility, University of North Carolina) for assistance with collection and analysis of BIAcore data. We thank Dr. Lawrence Quilliam (Indiana University) for supplying the cDNA for Grb2 SH2. We are grateful to Drs. Channing Der, Brian Kay, John O'Bryan, and Michael Schaller (University of North Carolina) for helpful discussions and to Drs. Sharon Milgram (University of North Carolina) and Robert Sealock for critically reading this manuscript.

Correspondence should be addressed to Dr. Stanley C. Froehner, Department of Physiology, Room 266 MSRB, Campus Box 7545, University of North Carolina at Chapel Hill, Chapel Hill, NC 27599.

Copyright (C) 1997 Society for Neuroscience $0270-6474 / 97 / 175038-08 \$ 05.00 / 0$ (for review, see Ullrich and Schlessinger, 1990; Heldin, 1995). The adaptor protein Grb2 is composed of a central $\mathrm{SH} 2$ domain flanked by two Src homology 3 (SH3) domains (Lowenstein et al., 1992). In the cytoplasm of unstimulated cells Grb2 is complexed via its two $\mathrm{SH} 3$ domains, with the Sos (son of sevenless) protein. On receptor activation, the complex is recruited to the cell membrane via the SH2 domain of Grb2, bringing Sos to the cellular location of its substrate protein Ras. Sos, a guanine-nucleotide exchange factor, converts Ras from its inactive GDP-bound state to its active GTP-bound state, leading to the activation of Rasdependent signaling pathways (for review, see Schlessinger, 1993, 1994).

The identification of ion channels, including potassium channels (Lev et al., 1995; Holmes et al., 1996), NMDA receptors (Moon et al., 1994; Wang and Salter, 1994; Lau and Huganir, 1995), and nicotinic acetylcholine receptors (AChRs) (Huganir et al., 1984; Qu et al., 1990), as substrates for tyrosine kinases suggests that this modification may play an important role in the regulation of synaptic function throughout the nervous system. The bulk of our knowledge about the functional consequences of tyrosine phosphorylation of ion channels comes from studies of the AChR at the neuromuscular junction (NMJ) and its homologous synapse in the electric organ of Torpedo. The AChR is a ligand-gated ion channel, composed of four homologous subunits in the stoichiometry $\alpha_{2} \beta \gamma \delta$, arranged around a central ion pore. Each subunit spans the membrane four times, with both $\mathrm{N}$ and $\mathrm{C}$ termini extending extracellularly (Galzi et al., 1991; Chavez and Hall, 1992). A large cytoplasmic loop between transmembrane domains three and four contains consensus sites for phosphorylation by multiple kinases (for review, see Swope et al., 1992). A single tyrosine residue in this region of the $\beta, \gamma$, and $\delta$ subunits of Torpedo AChR is phosphorylated by endogenous kinase activity in the postsynaptic membrane (Huganir et al., 1984; Wagner et al., 1991). Phosphorylation of the AChR by both serine and tyrosine kinases is associated with an increased rate of receptor desensitization (Huganir et al., 1986; Hopfield et al., 1988). In addition, 
agrin-induced tyrosine phosphorylation of the AChR may play a role in its clustering to high densities in the postsynaptic membrane of the neuromuscular junction (Qu et al., 1990; Wallace et al., 1991; Qu and Huganir, 1994; Wallace, 1994; Ferns et al., 1996).

In this study we provide evidence for an adaptor protein, Grb2, binding to the AChR, a ligand-gated ion channel. We show high-affinity binding between the $\mathrm{SH} 2$ domain of $\mathrm{Grb} 2$ and the phosphotyrosine site of the $\delta$ subunit of the AChR. The two proteins are colocalized on the innervated face of the electrocyte; furthermore, Grb2 specifically copurifies with the AChR solubilized from Torpedo postsynaptic membranes. Together these data demonstrate an association between the AChR and Grb2, which suggests a role for the $\mathrm{AChR}$ in initiating a signal transduction pathway involved in the assembly or maintenance of specializations at the synapse.

\section{MATERIALS AND METHODS}

Preparation of Torpedo membranes and isolation of AChR. Frozen Torpedo nobiliana electric organ was obtained from Biofish (Georgetown, MA). AChR-rich membranes were isolated as previously described (Porter and Froehner, 1983) with the omission of the second sucrose gradient step. This omission has negligible effect on the purity of the preparation. Iodoacetamide and $N$-ethylmaleimide also were omitted from all solutions. For isolation of AChR, membranes $(2 \mathrm{mg} / \mathrm{ml})$ were solubilized by incubation on ice for $30 \mathrm{~min}$ in extraction buffer [1\% Triton X-100, 150 $\mathrm{mm} \mathrm{NaCl}$, and $10 \mathrm{~mm}$ phosphate, $\mathrm{pH} 7.4$, including protease (Kramarcy et al., 1994) and phosphatase inhibitors (Lamphere and Lienhard, 1992)]. Insoluble material was removed by centrifugation at $40,000 \times g$ for $30 \mathrm{~min}$ at $4^{\circ} \mathrm{C}$. AChRs were isolated by incubating the supernatant with $\alpha$-bungarotoxin coupled to $\mathrm{CNBr}$-activated Sepharose 4B (Sigma, St. Louis, MO) for $2 \mathrm{hr}$ at $4^{\circ} \mathrm{C}$. As a control for specificity of binding to the resin, an equivalent sample of supernatant was incubated with excess $\alpha$-bungarotoxin $(25 \mu \mathrm{M})$ for $1 \mathrm{hr}$ at $4^{\circ} \mathrm{C}$ before incubation with the toxin-Sepharose. Beads were washed extensively with extraction buffer and equilibrated in the same buffer without detergent. Bound proteins were eluted with SDS sample buffer.

Dephosphorylation of Torpedo membrane proteins. Torpedo postsynaptic membranes $(100 \mu \mathrm{g})$ were diluted 10 -fold in phosphatase buffer (10 $\mathrm{mM} \mathrm{MgCl}_{2}, 10 \mathrm{~mm} \mathrm{ZnCl}$, and $100 \mathrm{~mm}$ glycine, $\left.\mathrm{pH} 10.4\right)$ and centrifuged at $40,000 \times g$ for $30 \mathrm{~min}$ at $4^{\circ} \mathrm{C}$. The pellet was resuspended in $200 \mu \mathrm{l}$ of phosphatase buffer containing $0.1 \%$ Triton X-100 to increase accessibility to the intravesicular compartment. Calf intestinal alkaline phosphatase (20 U; Pierce, Rockford, IL) was added to one-half of the sample (100 $\mu \mathrm{l})$ and incubated at $30^{\circ} \mathrm{C}$ for $2 \mathrm{hr}$. The reaction was stopped by the addition of SDS sample buffer. The second half of the sample was treated identically but with the omission of enzyme. Equivalent amounts $(5 \mu \mathrm{g})$ of phosphatase-treated and untreated Torpedo membrane proteins were resolved by SDS-PAGE, transferred to nitrocellulose, and analyzed by protein overlay assay and immunoblotting.

Protein overlay assay and immunoblotting. Proteins of Torpedo postsynaptic membranes or subunits of purified AChR were separated on $9 \%$ SDS gels and transferred to nitrocellulose membranes. Nitrocellulose blots were incubated for $1 \mathrm{hr}$ in blocking buffer (5\% milk, $0.1 \%$ Tween 20 , $150 \mathrm{~mm} \mathrm{NaCl}$, and $100 \mathrm{~mm}$ Tris, $\mathrm{pH} \mathrm{7.5).} \mathrm{Protein} \mathrm{overlay} \mathrm{assays} \mathrm{were}$ performed by using glutathione $S$-transferase (GST) fusion proteins of mouse Grb2 (GST-Grb2, amino acids 1-217) or individual domains of Grb2 (GST-Grb2 N-SH3, amino acids 1-68; GST-Grb2 SH2, amino acids 54-164; GST-Grb2 C-SH3, amino acids 156-199) (Santa Cruz Biotechnology, Santa Cruz, CA). Nitrocellulose membrane strips were incubated with GST fusion proteins ( $200 \mathrm{nM})$ in overlay buffer containing $3 \%$ BSA and (in mM) $150 \mathrm{NaCl}, 2 \mathrm{MgCl}_{2}, 1$ dithiothreitol, and 20 HEPES, $\mathrm{pH} 7.5$, overnight at $4^{\circ} \mathrm{C}$. Bound fusion proteins were detected with anti-GST monoclonal antibodies (mAb; 1:1000; Santa Cruz Biotechnology). Parallel membrane strips were analyzed by Western blotting with mAb 88B (90 pM) (Froehner et al., 1983), which recognizes both the $\gamma$ and $\delta$ subunits of the AChR or anti-phosphotyrosine mAb, 4G10 (1 $\mu \mathrm{g} / \mathrm{ml}$; Upstate Biotechnology, Lake Placid, NY), or PY20 $(1 \mu \mathrm{g} / \mathrm{ml}$; Transduction Laboratories, Lexington, KY). Grb2 was identified by immunoblotting with an anti-Grb2 mAb (1:4000; Transduction Laboratories). All primary antibody incubations were followed by incubation with horseradish peroxidase-conjugated secondary antibodies (1:3000; Jackson ImmunoResearch, West Grove, PA), and immunoreactive bands were visualized with enhanced chemiluminescence substrate (ECL; Pierce).

Immunofluorescence and confocal microscopy. Cryosections $(6 \mu \mathrm{m})$ of fixed Narcine brasiliensis electric organ were incubated in blocking buffer (1\% fish gelatin and 1\% BSA in PBS, $\mathrm{pH} 7.3$ ) containing BODIPY FL-conjugated $\alpha$-bungarotoxin (1:300; Molecular Probes, Eugene, OR) and rabbit anti-Grb2 antibodies (1:100; Santa Cruz Biotechnology), followed by incubation with Texas Red-conjugated anti-rabbit antibodies (1:200; Jackson ImmunoResearch). Digital images were acquired via a Leica TCS 4D confocal microscope.

Preparation of Grb2 SH2 fusion proteins. A GST fusion protein cDNA construct (pGEX-2t; Pharmacia, Piscataway, NJ) encoding the SH2 domain of Grb2 (amino acids 56-105) was generously provided by Dr. Lawrence Quilliam (Indiana University, IN). Large-scale protein expression in transformed Escherichia coli JM109 cells was induced with $1 \mathrm{~mm}$ isopropyl $\beta$-D-thiogalactopyranoside. Cells were lysed by sonication on ice, and fusion proteins were purified on glutathione-Sepharose beads (Pharmacia), followed by elution with $5 \mathrm{~mm}$ reduced glutathione. Protein concentration was determined by Bradford assay (Bio-Rad, Hercules, CA). Purified GST-Grb2 SH2 fusion proteins were exchanged into HEPES-buffered saline (HBS; $150 \mathrm{~mm} \mathrm{NaCl}, 3.4 \mathrm{~mm}$ EDTA, $0.005 \%$ surfactant P20, and $10 \mathrm{~mm}$ HEPES, $\mathrm{pH}$ 7.4) and used immediately in surface plasmon resonance assays.

Surface plasmon resonance-BIAcore. Surface plasmon resonance was used to determine quantitatively the strength of the interaction between Grb2 SH2 fusion proteins and $\delta$ subunit peptides in real time. This technique has been described in detail previously (Fagerstam, 1991; Johnsson et al., 1991). Biotinylated peptides corresponding to amino acids 388-401 (SKAQEYFNIKSRSE) of the Torpedo AChR $\delta$ subunit were synthesized (University of North Carolina Peptide Synthesis Facility) with either tyrosine or phosphotyrosine at position 393. Peptides were immobilized on a streptavidin-coated SA5 flow cell. HBS solutions containing different concentrations of GST-Grb2 SH2 $(31.3,62.5,125,250$, 500 , and $1000 \mathrm{nM}$ ) were injected onto the peptide surface, and subsequent binding was measured as an increase in resonance units (RU). The basic method for estimation of association and dissociation rate constants by BIAcore analysis has been described (Karlsson et al., 1991).

\section{RESULTS}

\section{Grb2 fusion proteins bind to the $\delta$ subunit of the AChR}

Many proteins important for synaptic function have their counterparts in the electric organ of marine rays, a tissue homologous to skeletal muscle. Postsynaptic membranes of this tissue have provided a rich source for the identification and characterization of many synaptic proteins, including rapsyn, syntrophin, and agrin (Sobel et al., 1977; Godfrey et al., 1984; Froehner et al., 1987). To identify potential binding partners for Grb2 in Torpedo postsynaptic membranes, we used a protein overlay assay in which GST fusion proteins were used to probe membrane proteins separated by SDS-PAGE and transferred to nitrocellulose. We consistently observed binding of GST-Grb2 fusion proteins, but not control GST proteins, to several proteins, the approximate molecular weights of which were 150, 130, 90, and $65 \mathrm{kDa}$ (Fig. 1, compare $C$ and $D$ ). The most prominent binding was to the $65 \mathrm{kDa}$ band. Parallel immunoblots showed that $\mathrm{mAb} 88 \mathrm{~B}$ (which recognizes both the $\gamma$ and $\delta$ subunits of the AChR) labeled the same position, suggesting that this band was the $\delta$ subunit of the AChR (Fig. $1 A$ ). To confirm that this protein was indeed the AChR $\delta$ subunit and not another protein migrating to the same position, we performed protein overlays on purified AChR, isolated by $\alpha$-bungarotoxin affinity chromatography. The amount of AChR was adjusted to be approximately equivalent to the amount of $\mathrm{AChR}$ present in the membrane samples as judged by immunoblotting with mAb $88 \mathrm{~B}$ (Fig. $1 A$ ). Figure $1, C$ and $D$, shows that GST-Grb2, but not control GST, binds directly to the $65 \mathrm{kDa} \delta$ subunit of isolated AChR. 
Figure 1. Grb2 binds to the $\delta$ subunit of the AChR. Torpedo postsynaptic membrane proteins $(M e m b)$ and isolated AChR subunits $(A C h R)$ were separated by SDS-PAGE and transferred to nitrocellulose membranes. $A$, Immunoblot with $\mathrm{mAb} 88 \mathrm{~B}$ indicates the position of the $\gamma$ and $\delta \mathrm{AChR}$ subunits. Higher molecular weight bands are aggregates and dimers of the $\delta$ subunit and degradation products thereof. Minor lower molecular weight bands are degradation products of the $\gamma$ and $\delta$ subunits. $B$, Tyrosine phosphorylation of the $\beta$ and $\delta$ subunits of the AChR is shown by Western blotting, using anti-phosphotyrosine (anti$P Y$ ) antibody 4G10. C, Protein overlays with control GST show no binding to membrane proteins or AChR subunits. $D$, Overlays with GST-Grb2 show binding to a prominent band at $65 \mathrm{kDa}$, corresponding to the $\delta$ subunit of the AChR. Other bands of 90, 130, and 150 $\mathrm{kDa}$ in membrane samples also were observed to bind Grb2. Arrows on the left indicate the position of the $\beta, \gamma$, and $\delta$ AChR subunits; numbers on the right indicate positions of molecular weight markers (in kDa).

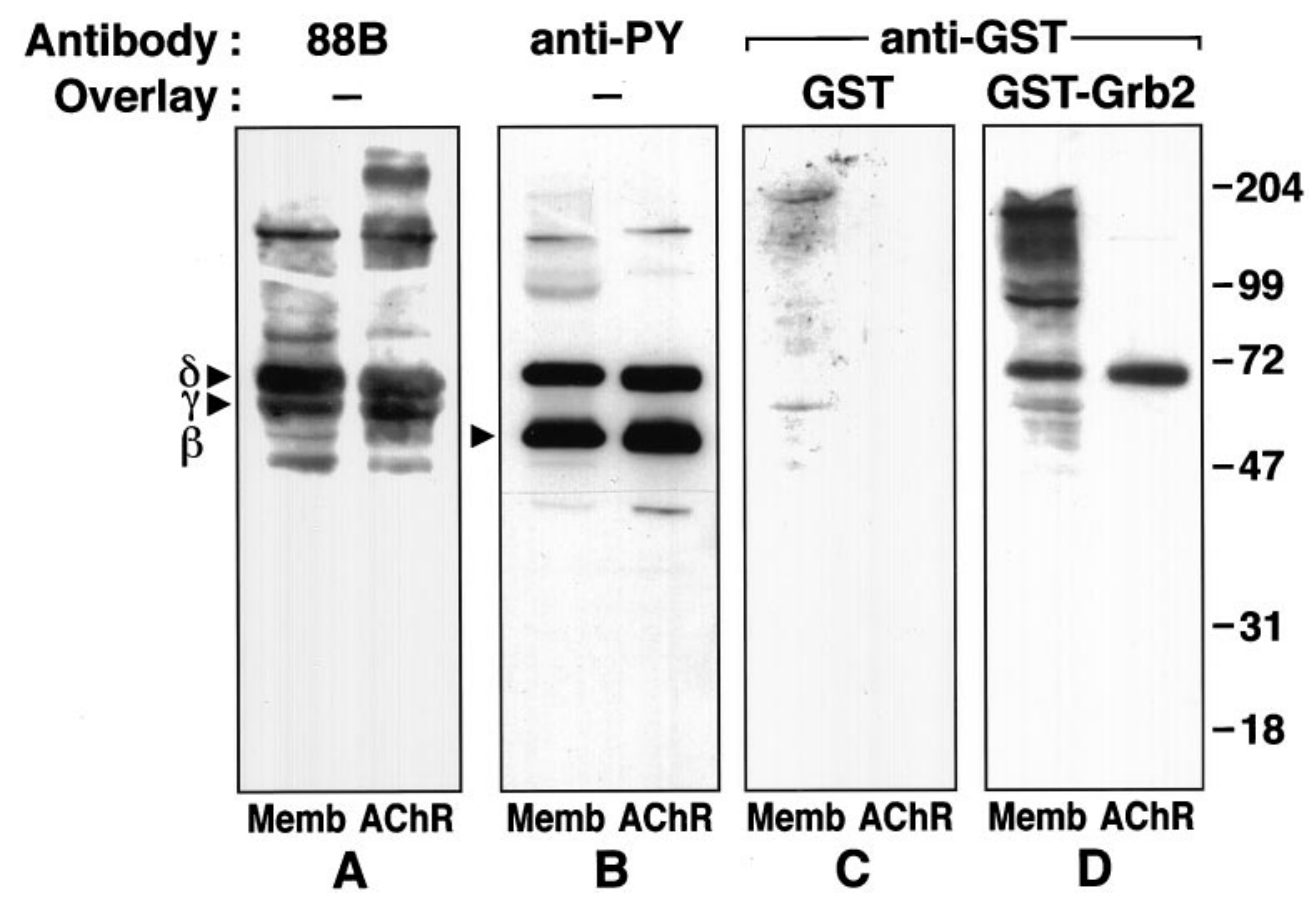

\section{Grb2- $\delta$ subunit binding is mediated by an SH2-phosphotyrosine interaction}

Grb2 consists of three protein-binding domains: a central $\mathrm{SH} 2$ domain flanked by $\mathrm{N}$ - and C-terminal SH3 domains. SH3 domains bind proline-rich sequences, whereas $\mathrm{SH} 2$ domains recognize phosphotyrosine motifs (for review, see Chardin et al., 1995). Examination of intracellular domain sequences of the $\delta$ subunit did not reveal any consensus sites for SH3 binding. Moreover, the AChR $\delta$ subunit is endogenously tyrosine-phosphorylated in our Torpedo membrane preparations (Fig. $1 B$ ), suggesting that the binding of Grb2 to the $\delta$ subunit could be mediated by the $\mathrm{SH} 2$ domain of Grb2. To test this hypothesis, we used fusion proteins corresponding to the three individual domains of Grb2 in overlay assays on isolated Torpedo AChR. As shown in Figure $2 A$, fusion proteins containing only the $\mathrm{SH} 2$ domain of Grb2, but neither of the $\mathrm{SH} 3$ domains, bind to the $\delta$ subunit of the AChR.

To test the specificity of the SH2-mediated interaction, we took advantage of the fact that three prominent Torpedo membrane proteins are tyrosine-phosphorylated by endogenous kinase(s): the $\beta$ and $\delta$ subunits of the AChR (50 and $65 \mathrm{kDa}$ ) and dystrobrevin (an $87 \mathrm{kDa}$ protein related to dystrophin) (Wagner et al., 1991, 1993). Phosphotyrosine immunoblots of our postsynaptic membrane preparations identify the AChR $\beta$ and $\delta$ subunits and an $87 \mathrm{kDa}$ band, which we presume to be dystrobrevin. We typically observe an additional phosphotyrosine protein at 130 $\mathrm{kDa}$, which may correspond to dimers of the $\delta$ subunit because this band also is recognized by mAb $88 \mathrm{~B}$ (Figs. $1 B, 2 B$, panel $B$ ). Phosphotyrosine was removed from membrane proteins by treatment with alkaline phosphatase, and dephosphorylated proteins were reassayed for Grb2 binding activity in overlay assays. Although an equivalent amount of $\delta$ subunit protein was present (Fig. $2 B$, panel $A$ ), the removal of phosphotyrosine (Fig. $2 B$, panel $B$ ) abolished the ability of GST-Grb2 to bind to the $65 \mathrm{kDa} \delta$ subunit in the alkaline phosphatase-treated sample (Fig. 2 B, panel $D)$. Binding to the 90 and $150 \mathrm{kDa}$ bands was retained, suggesting that these proteins may interact with the SH3 domain(s) of Grb2. Furthermore, although the $\beta$ subunit is phosphorylated to a level comparable to the $\delta$ subunit, we observed no binding to Grb2 fusion proteins (Figs. 1, 2). Thus the $\beta$ subunit provides a negative internal control in our overlay assays, further supporting the specificity of the Grb2 SH2- $\delta$ subunit association. Together these results indicate that Grb2 and the AChR $\delta$ subunit associate in vitro via an $\mathrm{SH} 2$ domain-phosphotyrosine-mediated interaction.

\section{A $\delta$ subunit phosphopeptide binds to the $\mathrm{SH} 2$ domain of Grb2}

The specificity of recognition of phosphotyrosine peptides by different SH2 domains is determined by the amino acid sequence immediately carboxyl to the phosphotyrosine (pY) residue (Songyang et al., 1993). Phosphopeptide library analysis predicts the optimal binding motif for the $\mathrm{SH} 2$ domain of $\mathrm{Grb} 2$ to be pYXNX ( $\mathrm{X}$ is any amino acid) (Songyang et al., 1994). The sequence that follows the phosphotyrosine site in the cytoplasmic loop of the $\delta$ subunit $\left(\mathrm{pY}_{393} \mathrm{FNI}\right)$ is a precise consensus for Grb2 $\mathrm{SH} 2$ binding, whereas sequences in homologous regions of the $\beta$ and $\gamma$ subunits do not conform to the Grb2 SH2 consensus motif (Fig. 3). This is in agreement with the finding that the tyrosinephosphorylated $\beta$ subunit does not bind Grb2 in overlay assays (see Figs. 1, 2).

We used surface plasmon resonance to assay quantitatively the binding between the $\mathrm{SH} 2$ domain of Grb2 and peptides corresponding to the phosphotyrosine consensus site of the $\delta$ subunit. This approach, which allows real-time measurement of binding kinetics and affinities, has been used previously to study interactions between different $\mathrm{SH} 2$ domains and tyrosine autophosphorylation sites of growth factor receptors (Felder et al., 1993; Panayotou et al., 1993; Lombardo et al., 1995). Tyrosinephosphorylated peptides $\left(\mathrm{pY}_{393}\right)$ corresponding to amino acids 388-401 of the Torpedo $\delta$ subunit were coupled to one cell of a sensor chip. Control peptides, containing tyrosine instead of phosphotyrosine at position 393, were coupled to a second cell. Several concentrations of Grb2 SH2 fusion proteins (31.3-1000 nм) were injected onto the sensor chip surface. Figure $4 A$ displays typical "sensorgrams" for binding of different concentrations of Grb2 
A.
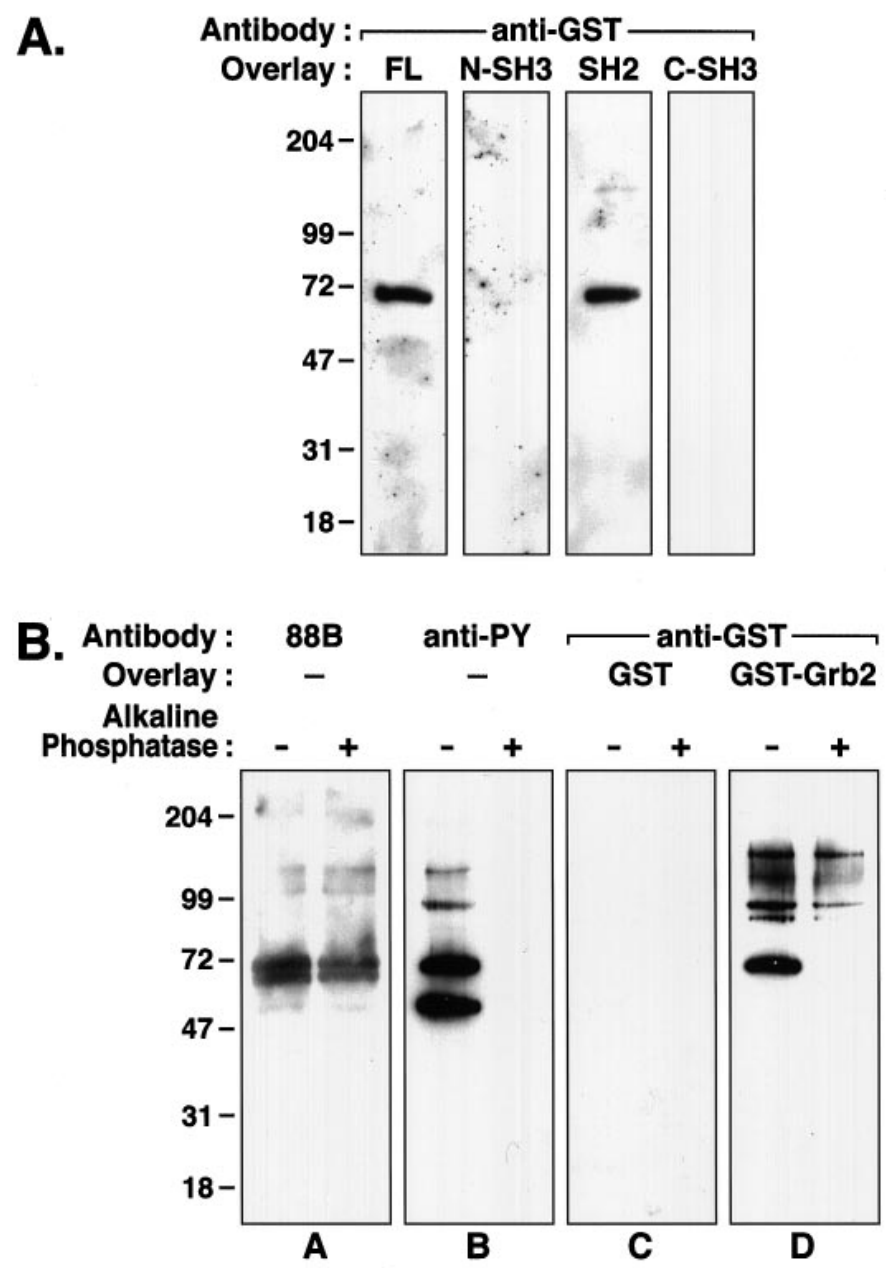

Figure 2. Grb2- $\delta$ subunit binding is mediated by an SH2-phosphotyrosine interaction. $A$, Isolated Torpedo AChR subunits were resolved by SDS-PAGE, transferred to nitrocellulose, and subjected to protein overlay analysis. Full-length GST-Grb2 (FL) binds to the $\delta$ subunit, as shown in Figure 1. No binding is observed with either $\mathrm{SH} 3$ domain fusion protein of Grb2 ( $N$-SH3 and $\mathrm{C}-\mathrm{SH} 3$ ). Fusion proteins containing the $\mathrm{SH} 2$ domain (SH2), however, bind to the $\delta$ subunit. $B$, Equivalent amounts of Torpedo membranes $(5 \mu \mathrm{g})$ treated with (right lane) and without (left lane) alkaline phosphatase were subjected to SDS-PAGE and transferred to nitrocellulose for protein overlay analysis. Panel $A$, Immunoblot with mAb $88 B$ shows that approximately equal amounts of $\delta$ subunit protein were loaded for each condition. Panel B, Parallel immunoblots, using a cocktail of anti-phosphotyrosine (anti-PY) antibodies, 4G10 and PY20, indicate an absence of immunoreactivity in the phosphatase-treated membranes. Panel C, Protein overlays with control GST show no binding. Panel D, Binding of full-length $G S T-G r b 2$ to the $\delta$ subunit is abolished by phosphatase treatment. Binding to the 90 and $150 \mathrm{kDa}$ bands is retained.

SH2 fusion proteins to immobilized $\delta$ subunit peptide. Robust, relatively rapid binding of the $\mathrm{SH} 2$ domain to the tyrosinephosphorylated peptide was observed. We found no binding to the nonphosphorylated peptide, even at the highest fusion protein concentration tested (1000 nM). In addition, control GST did not interact with the phosphorylated peptide (data not shown). Extrapolated steady-state binding responses were plotted as a function of fusion protein concentration (Fig. $4 B$ ). The dissociation constant $\left(K_{\mathrm{d}}\right)$ was estimated to be $226 \mathrm{~nm}$ by curve fitting, using nonlinear regression analysis. Thus, the $\mathrm{SH} 2$ domain of Grb2 binds to a tyrosine-phosphorylated peptide of the Torpedo $\delta$ subunit specifically and with relatively high affinity.

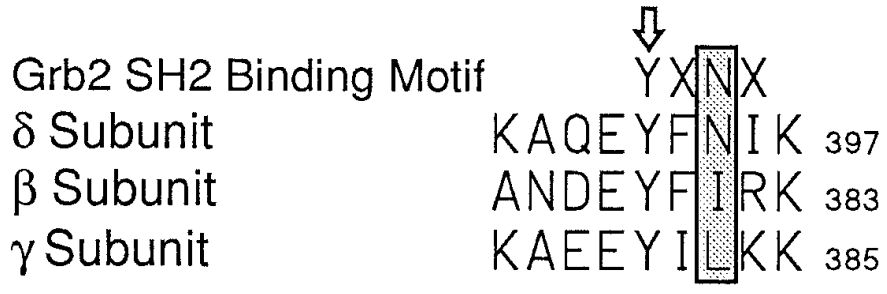

Figure 3. Tyrosine phosphorylation sites of Torpedo AChR subunits. Alignment of tyrosine phosphorylation sites in the large cytoplasmic loop of Torpedo $\beta, \gamma$, and $\delta$ subunits reveals a Grb2 $\mathrm{SH} 2$ consensus motif in the $\delta$ subunit, but not in the $\beta$ or $\gamma$ subunits. The $\mathrm{pY}+2$ position is boxed and shaded. The phosphotyrosine is indicated with an arrow.

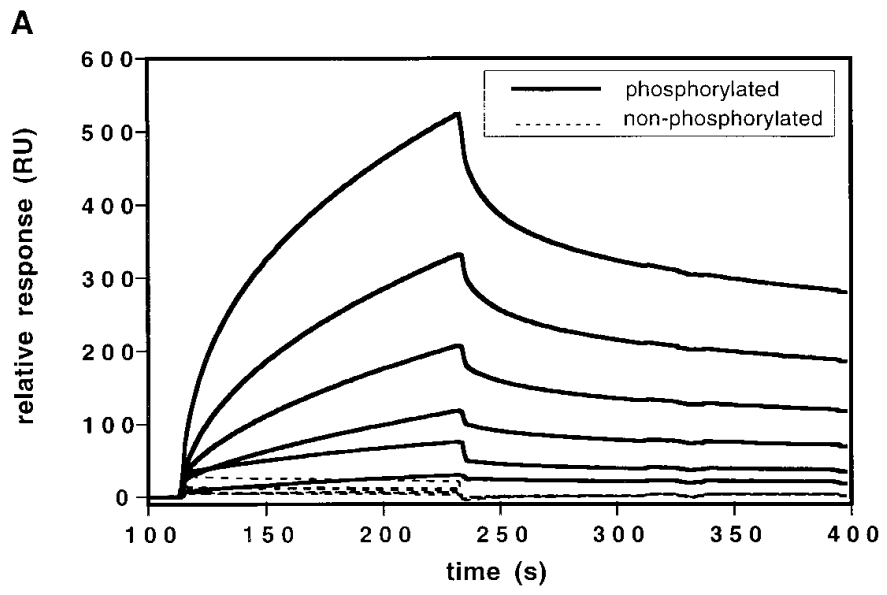

B

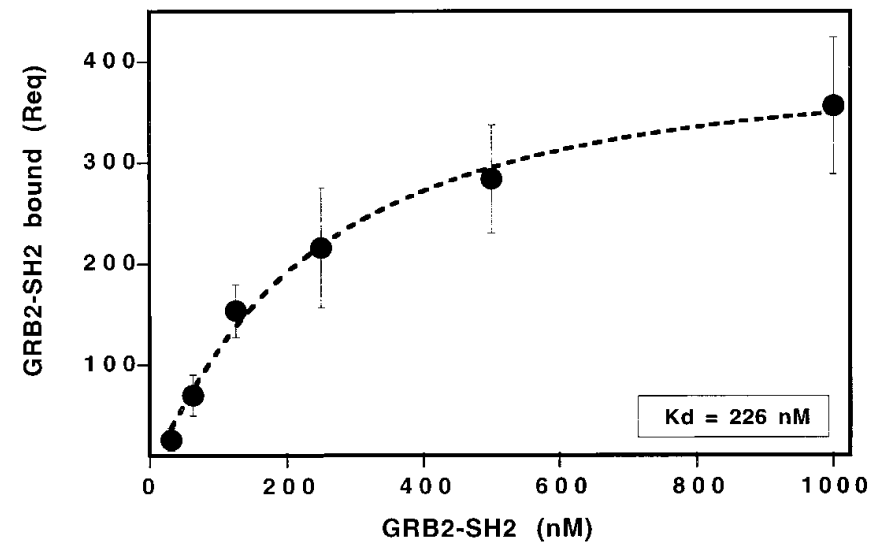

Figure 4. Interaction of the $\mathrm{SH} 2$ domain of Grb2 with a tyrosinephosphorylated $\delta$ subunit peptide. $A$, Raw binding data. Resonance signal $(R U)$ is plotted as a function of time for several concentrations of GST$\mathrm{Grb} 2 \mathrm{SH} 2$ injected onto the flow cell. Binding of fusion proteins to immobilized phosphorylated (solid line) and nonphosphorylated (broken line) $\delta$ subunit peptide is shown. Concentrations of fusion proteins injected were $31.3,62.5,125,250,500$, and $1000 \mathrm{nM}$. $B$, Determination of dissociation constant. Extrapolated steady-state binding responses (Req) are plotted versus fusion protein concentration. A dissociation constant $\left(K_{\mathrm{d}}\right)$ of $226 \mathrm{~nm}$ was estimated by nonlinear regression analysis.

\section{Grb2 binds to the AChR in Torpedo membranes}

Our biochemical data demonstrate that Grb2 and the AChR $\delta$ subunit are capable of direct association in vitro. As a first step toward determining whether they interact in vivo, AChR-rich electric organ membranes were immunoblotted with antibodies specific for Grb2. A protein of the appropriate size $(25 \mathrm{kDa})$ was 

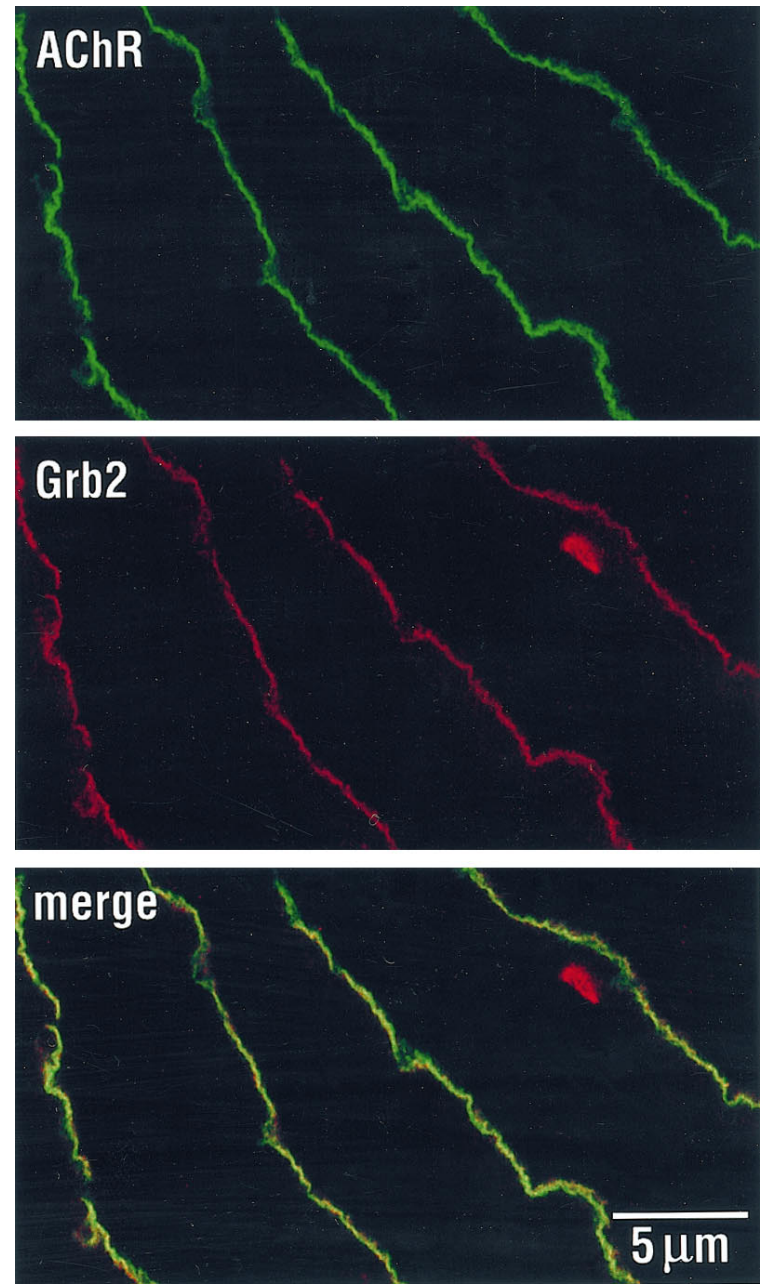

Figure 5. Grb2 and AChR are colocalized in electric organ postsynaptic membranes. Frozen Narcine electric organ sections $(6 \mu \mathrm{m})$ were labeled simultaneously for AChR with $\alpha$-bungarotoxin (top, green) and Grb2 (middle, red), processed for immunofluorescence, and analyzed by confocal microscopy. Grb2 antibodies label the innervated face of the electrocyte, in precise register with the AChR (bottom, merged image).

identified in the membranes by two different antibodies (data not shown), indicating that Grb2 is indeed a component of isolated postsynaptic membranes. However, the presence of Grb2 in our postsynaptic membrane preparations did not rule out the possibility that it was a contaminant derived from the noninnervated membrane of the electrocyte. To address this concern, we used confocal microscopy to investigate the subcellular localization of Grb2 relative to AChR in Narcine electroplax. Narcine electroplax are very similar to Torpedo but are better suited to immunofluorescence studies. As previously described (Sealock and Kavookjian, 1980), AChRs are restricted to the innervated face of the electrocyte (Fig. 5, top). Grb2 showed a strikingly similar pattern of labeling in these cells (Fig. 5, middle). In fact, merging the two images (Fig. 5, bottom) indicated that Grb2 is localized in precise register with the AChR on the innervated face of the electrocyte.

To address whether the two molecules form a complex in the cell, we asked whether Grb2 copurifies with AChR. To this end, postsynaptic membranes were extracted in $1 \%$ Triton X-100 and AChR isolated by $\alpha$-bungarotoxin beads. Bound proteins were eluted with SDS-sample buffer and analyzed by immunoblotting

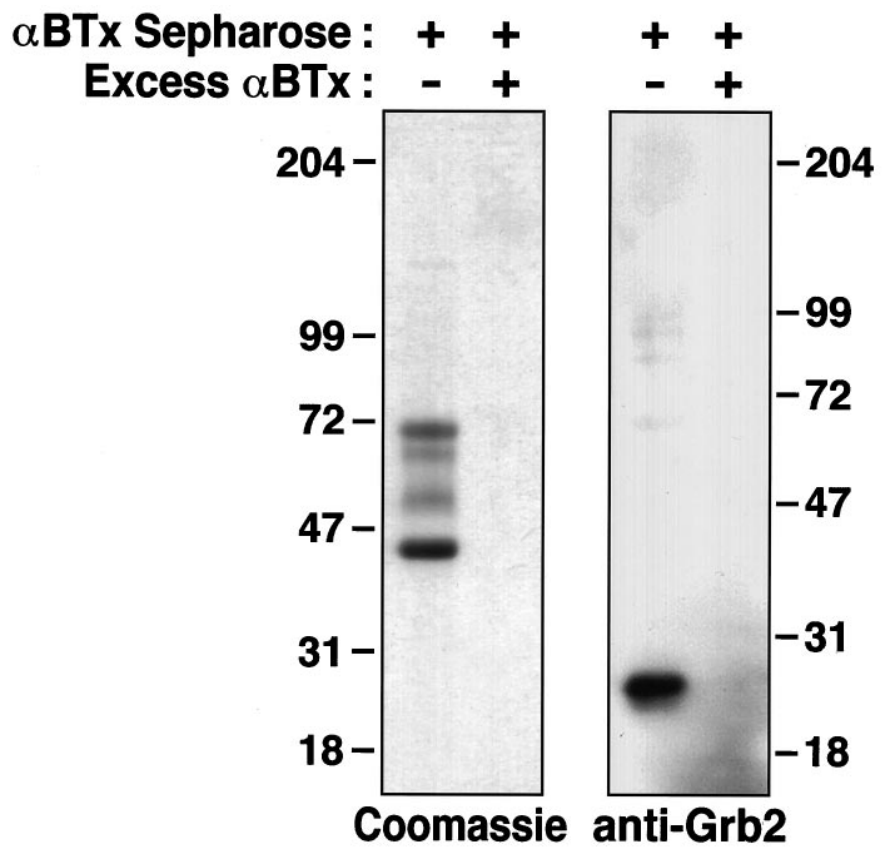

Figure 6. Grb2 associates with the AChR in situ. AChRs were isolated from solubilized Torpedo membranes by $\alpha$-bungarotoxin-Sepharose, were eluted in SDS, and were resolved by SDS-PAGE. Coomassie staining of the preparation shows the four subunits of the AChR: $\alpha, \sim 40 \mathrm{kDa} ; \beta, \sim 50$ $\mathrm{kDa} ; \gamma, \sim 60 \mathrm{kDa}$; and $\delta, \sim 65 \mathrm{kDa}$. Preincubation with excess $\alpha$-bungarotoxin $(25 \mu \mathrm{M})$ prevents binding of AChR to the toxin-Sepharose (left). Immunoblotting the samples with anti-Grb2 antibodies reveals that Grb2 specifically copurifies with the AChR (right).

with antibodies specific for Grb2. As shown in Figure 6, Grb2 specifically copurifies with the AChR. When binding of AChR to the beads was blocked by preincubation of solubilized membranes with excess toxin, Grb2 was not retained, indicating that the binding of Grb2 specifically depends on the presence of AChR on the beads. Although AChR subunits are easily detected by Coomassie staining, we did not observe a band corresponding in size to Grb2 in the AChR preparation (Fig. 6, left). Thus, at least under these purification conditions, the stoichiometry of Grb2 to AChR is low. This observation is not inconsistent with the signaling role of Grb2. Linking a small percentage of tyrosinephosphorylated AChR to downstream enzymatic pathways likely would be sufficient to activate a signaling cascade. It is also possible that the association between the AChR and Grb2 may be disrupted partially under the purification conditions that we used. Thus, although a small proportion of AChR seems to be associated with Grb2 under these circumstances, the interaction is nevertheless significant. These results suggest that Grb2 and the $\delta$ subunit of the nicotinic AChR associate in vivo.

\section{DISCUSSION}

We have identified a previously unsuspected interaction between the tyrosine-phosphorylated AChR and the SH2 domain of Grb2. Several lines of evidence support the specificity of this association. Protein overlay assays demonstrate that GST fusion proteins of Grb2, but not control GST proteins, directly bind to the AChR $\delta$ subunit in Torpedo postsynaptic membranes. Fusion proteins containing only the $\mathrm{SH} 2$ domain of Grb2, but neither of the $\mathrm{SH} 3$ domains, bind to the $\delta$ subunit. Dephosphorylation of the $\delta$ subunit completely abolishes Grb2 binding. Although the $\beta$ subunit of the AChR also is tyrosine-phosphorylated in our mem- 
brane preparations, we observed no interaction with Grb2 in overlay assays. The Torpedo $\delta$ subunit contains a precise motif (pYXNX) for recognition by the SH2 domain of Grb2 that is not present in homologous regions of the $\beta$ or $\gamma$ subunits. A phosphotyrosine peptide corresponding to this region of the $\delta$ subunit interacts with Grb2 SH2 fusion proteins with relatively high affinity, whereas a peptide lacking phosphorylation on tyrosine exhibits no binding. Thus, we have narrowed the binding site for Grb2 to within 14 amino acids surrounding the site of tyrosine phosphorylation in the long intracellular loop of the $\delta$ subunit. Furthermore, we have demonstrated that Grb2 has a subcellular distribution identical to that of the AChR in the electrocyte; both molecules are concentrated at and restricted to the innervated membrane. Finally, isolation of the AChR from solubilized electric organ results in the specific copurification of Grb2, indicating that the two molecules form a complex in situ.

A clue to the function of this association may come from identification of SH3 binding partners for Grb2 in the postsynaptic membrane. One possibility is suggested by the recent finding that Grb2 can bind, via its SH3 domain(s), to a proline-rich region of $\beta$-dystroglycan (Yang et al., 1995). $\beta$-Dystroglycan is a component of the dystrophin-glycoprotein complex, serving as a transmembrane link between the extracellular peripheral membrane protein $\alpha$-dystroglycan and cytoskeletal dystrophin or utrophin (Ibraghimov-Beskrovnaya et al., 1992). Recently, $\alpha$-dystroglycan was identified as a cell surface binding site for agrin (Bowe et al., 1994; Campanelli et al., 1994; Gee et al., 1994; Sugiyama et al., 1994). This finding has focused much attention on the possible role of the dystrophin-protein complex in mediating the AChR clustering effects of agrin. If AChR-bound Grb2 were also to bind $\beta$-dystroglycan via its $\mathrm{SH} 3$ domains, Grb2 could provide a direct link between the AChR and the dystrophin/utrophin protein complex. However, we have found no evidence for an interaction between Grb2 and $\beta$-dystroglycan in our studies. Although we confirmed, by Western blotting, the presence of $\beta$-dystroglycan in our Torpedo membrane preparations (Bowe et al., 1994) (data not shown), we observed no binding of Grb2 to a protein corresponding in size to $\beta$-dystroglycan (43 kDa) in overlay assays (see Fig. $1 D)$. In addition, in affinity purification experiments, we did not observe copurification of $\beta$-dystroglycan with complexes containing the AChR and Grb2 (data not shown). Ruling out technical or species differences, we cannot explain the apparent discrepancy between our results and those of Yang et al. (1995) at this time. Interestingly, we observed binding of Grb2 to proteins of 90 and $150 \mathrm{kDa}$ in our overlay assays (see Fig. 1) that did not depend on phosphorylation (see Fig. $2 B$, panel $D$ ). Future studies will address whether these may represent SH3 binding partners for Grb2 at the synapse.

One important question is whether the association between Grb2 and the AChR occurs in mammals, particularly at the NMJ. Alignment of $\delta$ subunit amino acid sequences from different species reveals that the asparagine in the $\mathrm{pY}+2$ position, which is important for recognition by the $\mathrm{SH} 2$ domain of $\mathrm{Grb} 2$, is not conserved. Mammalian $\delta$ subunit orthologs contain a serine in this position. Yet the preference for hydrophobic amino acids at the $\mathrm{pY}+1$ and +3 positions (Song-yang et al., 1994) is conserved in mammals (mouse, pYFSL). Whether serine can substitute for asparagine in the Grb2 SH2 binding site is not known. Certainly, in vitro peptide library analysis indicates a strong preference for asparagine in this position (Songyang et al., 1994). Association between phosphorylated mouse $\delta$ subunit peptides and Grb2 SH2 fusion proteins was not detected in preliminary surface plasmon resonance assays (data not shown), suggesting that the affinity of the interaction, if it occurs at all, is low. It is interesting to consider whether a low-affinity interaction would be sufficient to mediate signaling at the mammalian endplate, where the density of AChR approaches 10,000 per square micron. This high local concentration may compensate for a weak interaction between Grb2 and the mammalian $\delta$ subunit and, in fact, may necessitate low-affinity interactions for rapid onset and termination of signaling. In addition, it was reported recently that the Grb2-Sos complex binds phosphopeptides with higher affinity than Grb2 alone (Chook et al., 1996). This raises the possibility that the functional in vivo binding partner for the AChR may be Grb2 complexed with Sos or another protein such as $\beta$-dystroglycan. Thus, although the sequence surrounding the mammalian tyrosine phosphorylation site is less than optimal for Grb2 binding, it still may be an important mediator of transmembrane signaling.

Identification of upstream tyrosine kinase pathways, especially those mediating $\delta$ subunit phosphorylation, may provide insight into the function of the association of Grb2 with the AChR. One synaptic molecule implicated in the activation of a tyrosine kinase pathway is agrin. This nerve-derived protein originally was isolated for its striking ability to cause AChR aggregation in chick myotubes (Godfrey et al., 1984). The observation that agrin induces tyrosine phosphorylation of the $\beta$ (Wallace et al., 1991; $\mathrm{Qu}$ and Huganir, 1994; Wallace, 1994; Ferns et al., 1996), and perhaps the $\delta$ (Qu and Huganir, 1994), subunit of the AChR has led to the hypothesis that this is a critical, and perhaps a prerequisite, step in the AChR clustering pathway. A recently identified musclespecific receptor tyrosine kinase, MuSK, has been shown to be essential for NMJ formation (Valenzuela et al., 1995; DeChiara et al., 1996). Indeed, MuSK can be activated by agrin and is a component of the receptor complex for agrin (Glass et al., 1996). Activation of MuSK results specifically in tyrosine phosphorylation of the $\beta$, but not the $\delta$, subunit of the AChR in vitro (Gillespie et al., 1996; Glass et al., 1996), suggesting that it does not catalyze $\delta$ subunit phosphorylation in vivo.

Tyrosine kinases of the Src family have been identified in association with the AChR. In electric organ, coimmunoprecipitation experiments demonstrated that tyrosine-phosphorylated AChRs are complexed with Fyn and a novel member of this family, Fyk (Swope and Huganir, 1993). The binding seems to be mediated by the SH2 domains of the kinases and the $\delta$ subunit of the AChR (Swope and Huganir, 1994). This raises the possibility that the SH2 domains of Fyn and Fyk may compete with Grb2 for binding to the $\delta$ subunit. However, this idea is contrary to recent studies that suggest that specificity in tyrosine kinase signaling may result, in part, from the ability of different $\mathrm{SH} 2$ domains to distinguish among different target sequences (Songyang et al., 1993). The optimal sequence for binding to Fyn SH2 domains is pYEEI, as compared with the optimal Grb2 SH2 binding site of pYXNX (Songyang et al., 1994). The $\delta$ subunit phosphotyrosine site of pYFNI is a precise motif for Grb2 SH2 binding, whereas only the isoleucine in the third position is consistent with recognition by the $\mathrm{SH} 2$ domain of Fyn. Whether the $\delta$ subunit interacts with various $\mathrm{SH} 2$ domain-containing proteins remains to be resolved. Regardless, the $\delta$ subunit does not seem to be a substrate of Fyn and Fyk, because their binding to the AChR requires tyrosine phosphorylation.

An interaction between Src and the mammalian AChR recently has been reported (Fuhrer and Hall, 1996). The binding seems to be mediated by an $\mathrm{N}$-terminal unique region of the kinase and the intracellular loop of the $\beta$ subunit. Src was able to tyrosine 
phosphorylate $\beta$ subunit fusion proteins in vitro. AChRs, affinitypurified from mouse myotubes, were associated with both Src and Fyn and contained tyrosine-phosphorylated $\beta$ subunit. There was no evidence for Src association with, or phosphorylation of, the $\delta$ subunit in these studies. Thus, it is not likely that Src family kinases catalyze $\delta$ subunit phosphorylation.

Although the kinase responsible for tyrosine phosphorylation of the $\delta$ subunit remains a mystery, it is interesting to note that the amino acid sequence preceding $\mathrm{Y}_{393}$ of the $\delta$ subunit forms a consensus motif for phosphorylation by members of the receptor tyrosine kinase family (Songyang et al., 1995a). An intriguing possibility is that the ARIA/erbB receptor tyrosine kinase pathway may be involved. ARIA (acetylcholine receptor-inducing activity) originally was isolated from chick brain extracts for its ability to promote the synthesis of AChR subunits in aneural myotubes (Jessell et al., 1979). Induction of AChR gene expression by ARIA recently was shown to require activation of the MAP kinase and PI3 kinase pathways via the erbB receptors (Si et al., 1996; Tansey et al., 1996). The model predicts that ARIA may bind to an erbB2/erbB3 heterodimer and in doing so may activate the Ras/MAP kinase pathway through erbB2 and the PI3 kinase pathway through erbB3 (Tansey et al., 1996). One possibility is that ARIA stimulation of erbB2 may lead to AChR phosphorylation, recruiting Grb2 to the postsynaptic membrane via its $\mathrm{SH} 2$ domain. In turn, this could lead to activation of the Ras/MAP kinase signal transduction pathway, ultimately inducing AChR subunit gene expression.

\section{REFERENCES}

Blaikie P, Immanuel D, Wu J, Li N, Yajnik V, Margolis B (1994) A region in Shc distinct from the $\mathrm{SH} 2$ domain can bind tyrosinephosphorylated growth factor receptors. J Biol Chem 269:32031-32034.

Bowe MA, Deyst KA, Leszyk JD, Fallon JR (1994) Identification and purification of an agrin receptor from Torpedo postsynaptic membranes: a heteromeric complex related to the dystroglycans. Neuron 12:1173-1180.

Campanelli JT, Roberds SL, Campbell KP, Scheller RH (1994) A role for dystrophin-associated glycoproteins and utrophin in agrin-induced AChR clustering. Cell 77:663-674.

Chardin P, Cussac D, Maignan S, Ducruix A (1995) The Grb2 adaptor. FEBS Lett 369:47-51.

Chavez RA, Hall ZW (1992) Expression of fusion proteins of the nicotinic acetylcholine receptor from mammalian muscle identifies the membrane-spanning regions in the $\alpha$ and $\delta$ subunits. J Cell Biol 116:385-393.

Chook YM, Gish GD, Kay CM, Pai EF, Pawson T (1996) The Grb2mSos1 complex binds phosphopeptides with higher affinity than Grb2. J Biol Chem 271:30472-30478.

Cohen GB, Ren R, Baltimore D (1995) Modular binding domains in signal transduction proteins. Cell 80:237-248.

DeChiara TM, Bowen DC, Valenzuela DM, Simmons MV, Poueymirou WT, Thomas S, Kinetz E, Compton DL, Rojas E, Park JS, Smith C, DiStefano PS, Glass DJ, Burden SJ, Yancopoulos GD (1996) The receptor tyrosine kinase MuSK is required for neuromuscular junction formation in vivo. Cell 85:501-512.

Fagerstam L (1991) A non-label technology for real time biospecific interaction analysis. In: Techniques in protein chemistry II (Villanova JJ, ed), pp 65-71. New York: Academic.

Felder S, Zhou M, Hu P, Urena J, Ullrich A, Chaudhuri M, White M, Shoelson E, Schlessinger J (1993) SH2 domains exhibit high-affinity binding to tyrosine-phosphorylated peptides yet also exhibit rapid dissociation and exchange. Mol Cell Biol 13:1449-1455.

Ferns M, Deiner M, Hall Z (1996) Agrin-induced acetylcholine receptor clustering in mammalian muscle requires tyrosine phosphorylation. J Cell Biol 132:937-944.

Froehner SC, Douville K, Klink S, Culp WJ (1983) Monoclonal antibodies to cytoplasmic domains of the acetylcholine receptor. J Biol Chem 258:7112-7120.

Froehner SC, Murnane AA, Tobler M, Peng HB, Sealock R (1987) A postsynaptic $M_{\mathrm{r}} 58,000(58 \mathrm{~K})$ protein at acetylcholine receptor-rich sites in Torpedo electroplaques and skeletal muscle. J Cell Biol 104:1633-1646.

Fuhrer C, Hall ZW (1996) Functional interaction of Src family kinases with the acetylcholine receptor in $\mathrm{C} 2$ myotubes. J Biol Chem 271:32474-32481.

Galzi J-L, Revah F, Bessis A, Changeux J-P (1991) Functional architecture of the nicotinic acetylcholine receptor: from electric organ to brain. Annu Rev Pharmacol 31:37-72.

Gee SH, Montanaro F, Lindenbaum MH, Carbonetto S (1994) Dystroglycan- $\alpha$, a dystrophin-associated glycoprotein, is a functional agrin receptor. Cell 77:675-686.

Gillespie SKH, Balasubramanian S, Fung ET, Huganir RL (1996) Rapsyn clusters and activates the synapse-specific receptor tyrosine kinase MuSK. Neuron 16:953-962.

Glass DJ, Bowen DC, Stitt TN, Radziejewski C, Bruno J, Ryan TE, Gies DR, Shah S, Mattsson K, Burden SJ, DiStefano PS, Valenzuela DM, DeChiara TM, Yancopoulos GD (1996) Agrin acts via a MuSK receptor complex. Cell 85:513-523.

Godfrey EW, Nitkin RM, Wallace BG, Rubin LL, McMahan UJ (1984) Components of Torpedo electric organ and muscle that cause aggregation of acetylcholine receptors on cultured muscle cells. J Cell Biol 99:615-627.

Heldin C-H (1995) Dimerization of cell surface receptors in signal transduction. Cell 80:213-223.

Holmes TC, Fadool DA, Ren R, Levitan IB (1996) Association of Src tyrosine kinase with a human potassium channel mediated by $\mathrm{SH} 3$ domain. Science 274:2089-2091.

Hopfield JF, Tank DW, Greengard P, Huganir RL (1988) Functional modulation of the nicotinic acetylcholine receptor by tyrosine phosphorylation. Nature 336:677-680.

Huganir RL, Miles K, Greengard P (1984) Phosphorylation of the nicotinic acetylcholine receptor by an endogenous tyrosine-specific protein kinase. Proc Natl Acad Sci USA 81:6968-6972.

Huganir RL, Delcour AH, Greengard P, Hess GP (1986) Phosphorylation of the nicotinic acetylcholine receptor regulates its rate of desensitization. Nature 321:774-776.

Ibraghimov-Beskrovnaya O, Ervasti JM, Leveille CJ, Slaughter CA, Sernett SW, Campbell KP (1992) Primary structure of dystrophinassociated glycoproteins linking dystrophin to the extracellular matrix. Nature 355:696-702.

Jessell TM, Siegel RE, Fischbach GD (1979) Induction of acetylcholine receptors on cultured skeletal muscle by a factor extracted from brain and spinal cord. Proc Natl Acad Sci USA 76:5397-5401.

Johnsson B, Lofas S, Lindquist G (1991) Immobilization of proteins to a carboxymethyl dextran-modified gold surface for biospecific interaction analysis in surface plasmon resonance sensors. Anal Biochem 198:268-277.

Karlsson R, Michaelsson A, Mattson L (1991) Kinetic analysis of monoclonal antibody-antigen interactions with a new biosensor-based analytical system. J Immunol Methods 145:229-240.

Kavanaugh WM, Williams LT (1994) An alternative to SH2 domains for binding tyrosine-phosphorylated proteins. Science 266:1862-1864.

Kavanaugh WM, Turck CW, Williams LT (1995) PTB domain binding to signaling proteins through a sequence motif containing phosphotyrosine. Science 268:1177-1179.

Koch CA, Anderson D, Moran MF, Ellis C, Pawson T (1991) SH2 and SH3 domains: elements that control interactions of cytoplasmic signaling proteins. Science 252:668-674.

Kramarcy NR, Vidal A, Froehner SC, Sealock R (1994) Association of utrophin and multiple dystrophin short forms with the mammalian $M_{\mathrm{r}}$ 58,000 dystrophin-associated protein (syntrophin). J Biol Chem 269:2870-2876.

Lamphere L, Lienhard GE (1992) Components of signaling pathways for insulin and insulin-like growth factor-1 in muscle myoblasts and myotubes. Endocrinology 131:2196-2202.

Lau L-F, Huganir RL (1995) Differential tyrosine phosphorylation of $N$-methyl-D-aspartate receptor subunits. J Biol Chem 270:20036-20041.

Lev S, Moreno H, Martinez R, Canoll P, Peles E, Musacchio JM, Plowman GD, Rudy B, Schlessinger J (1995) Protein tyrosine kinase PYK2 involved in calcium-induced regulation of ion channel and MAP kinase functions. Nature 376:737-745.

Lombardo CR, Consler TG, Kassel DB (1995) In vitro phosphorylation of the epidermal growth factor receptor autophosphorylation domain by 
c-src: identification of phosphorylation sites and c-src SH2 domain binding sites. Biochemistry 34:16456-16466.

Lowenstein EJ, Daly RJ, Batzer AG, Li W, Margolis B, Lammers R, Ullrich A, Skolnik EY, Bar-Sagi D, Schlessinger J (1992) The SH2 and SH3 domain-containing protein Grb2 links receptor tyrosine kinases to ras signaling. Cell 70:431-442.

Moon IS, Apperson ML, Kennedy MB (1994) The major tyrosinephosphorylated protein in the postsynaptic density fraction is $N$-methylD-aspartate receptor subunit 2B. Proc Natl Acad Sci USA 91:3954-3958.

Panayotou G, Gish G, End P, Truong O, Gout I, Dhand R, Fry MJ, Hiles I, Pawson T, Waterfield MD (1993) Interactions between SH2 domains and tyrosine-phosphorylated platelet-derived growth factor $\beta$-receptor sequences: analysis of kinetic parameters by a novel biosensor-based approach. Mol Cell Biol 13:3567-3576.

Pawson T (1995) Protein modules and signalling networks. Nature 373:573-580.

Porter S, Froehner SC (1983) Characterization and localization of the $M_{r}$ $=43,000$ proteins associated with acetylcholine receptor-rich membranes. J Biol Chem 258:10034-10040.

Qu Z, Huganir RL (1994) Comparison of innervation and agrin-induced tyrosine phosphorylation of the nicotinic acetylcholine receptor. J Neurosci 14:6834-6841.

Qu Z, Moritz E, Huganir RL (1990) Regulation of tyrosine phosphorylation of the nicotinic acetylcholine receptor at the rat neuromuscular junction. Neuron 4:367-378.

Schlessinger J (1993) How receptor tyrosine kinases activate Ras. Trends Biochem Sci 18:273-275.

Schlessinger J (1994) SH2/SH3 signaling proteins. Curr Opin Genet Dev 4:25-30.

Sealock R, Kavookjian A (1980) Postsynaptic distribution of acetylcholine receptors in electroplax of the Torpedine ray, Narcine brasiliensis. Brain Res 190:81-93.

Si J, Luo Z, Mei L (1996) Induction of acetylcholine receptor gene expression by ARIA requires activation of mitogen-activated protein kinase. J Biol Chem 271:19752-19759.

Sobel A, Weber M, Changeux J-P (1977) Large scale purification of the acetylcholine receptor protein in its membrane-bound and detergentextracted forms from Torpedo marmorata electric organ. Eur J Biochem 80:215-244.

Songyang Z, Shoelson SE, Chaudhuri M, Gish G, Pawson T, Haser WG, King F, Roberts T, Ratnofsky S, Lechleider RJ, Neel BG, Birge RB, Fajardo JE, Chou MM, Hanafusa H, Schaffhausen B, Cantley LC (1993) SH2 domains recognize specific phosphopeptide sequences. Cell 72:767-778.

Songyang Z, Shoelson SE, McGlade J, Olivier P, Pawson T, Bustelo XR, Barbacid M, Sabe H, Hanafusa H, Yi T, Ren R, Baltimore D, Ratnofsky S, Feldman RA, Cantley LC (1994) Specific motifs recognized by the
SH2 domains of Csk, 3BP2, fps/fes, GRB-2, HCP, SHC, Syk, and Vav. Mol Cell Biol 14:2777-2785.

Songyang Z, Carraway KL, Eck MJ, Harrison SC, Feldman RA, Mohammadi M, Schlessinger J, Hubbard SR, Smith DP, Eng C, Lorenzo MJ, Ponder BAJ, Mayer BJ, Cantley LC (1995a) Catalytic specificity of protein-tyrosine kinases is critical for selective signalling. Nature 373:536-539.

Songyang Z, Margolis B, Chaudhuri M, Shoelson SE, Cantley LC (1995b) The phosphotyrosine interaction domain of SHC recognizes tyrosinephosphorylated NPXY motif. J Biol Chem 270:14863-14866.

Sugiyama J, Bowen DC, Hall ZW (1994) Dystroglycan binds nerve and muscle agrin. Neuron 13:103-115.

Swope SL, Huganir RL (1993) Molecular cloning of two abundant protein tyrosine kinases in Torpedo electric organ that associate with the acetylcholine receptor. J Biol Chem 268:25152-25161.

Swope SL, Huganir RL (1994) Binding of the nicotinic acetylcholine receptor to $\mathrm{SH} 2$ domains of Fyn and Fyk protein tyrosine kinases. J Biol Chem 269:29817-29824.

Swope SL, Moss SJ, Blackstone CD, Huganir RL (1992) Phosphorylation of ligand-gated ion channels: a possible mode of synaptic plasticity. FASEB J 6:2514-2523.

Tansey MG, Ghu GC, Merlie JP (1996) ARIA/HRG regulates AChR $\epsilon$ subunit gene expression at the neuromuscular synapse via activation of phosphatidylinositol 3-kinase and Ras/MAPK pathway. J Cell Biol 134:465-476.

Ullrich A, Schlessinger J (1990) Signal transduction by receptors with tyrosine kinase activity. Cell 61:203-212.

Valenzuela DM, Stitt TN, DiStefano PS, Rojas E, Mattsson K, Compton DL, Nunez L, Park JS, Stark JL, Gies DR, Thomas S, Le Beau MM, Fernald AA, Copeland NG, Jenkins NA, Burden SJ, Glass DJ, Yancopoulos GD (1995) Receptor tyrosine kinase specific for the skeletal muscle lineage: expression in embryonic muscle, at the neuromuscular junction, and after injury. Neuron 15:573-584.

Wang YT, Salter MW (1994) Regulation of NMDA receptors by tyrosines and phosphatases. Nature 369:233-235.

Wagner K, Edson K, Heginbotham L, Post M, Huganir RL, Czernik AJ (1991) Determination of the tyrosine phosphorylation sites of the nicotinic acetylcholine receptor. J Biol Chem 266:23784-23789.

Wagner KR, Cohen JB, Huganir RL (1993) The 87K postsynaptic membrane protein from Torpedo is a protein-tyrosine kinase substrate homologous to dystrophin. Neuron 10:511-522.

Wallace BG (1994) Staurosporine inhibits agrin-induced acetylcholine receptor phosphorylation and aggregation. J Cell Biol 125:661-668.

Wallace BG, Qu Z, Huganir RL (1991) Agrin induces phosphorylation of the nicotinic acetylcholine receptor. Neuron 6:869-878.

Yang B, Jung D, Motto D, Meyer J, Koretzy G, Campbell K (1995) SH3 domain-mediated interaction of dystroglycan and Grb2. J Biol Chem 270:11711-11714. 